\title{
The Effect of Circuit Training Methods, Circuit Series and Learning Motivation on Students' Volleyball Basic Skill
}

\author{
Yuni Astuti ${ }^{*}$, Ali Mardius² \\ 1,2 Program Studi Pendidikan Jasmani Kesehatan dan Rekreasi Fakultas Keguruan dan Ilmu Pendidikan, Universitas Bung Hatta, \\ Padang
}

\section{A R T I C L E I N F O}

Article history:

Received 20 May 2018

Received in revised

form

6 June 2018

Accepted 15 July 2018

Available online 25

August 2018

\section{Keywords:}

Circuit training, play series, learning

motivation, volleyball

basic technical skill

\begin{abstract}
A B S T R A CT
This research was conducted to reveal the influence of circuit training methods, circuit series and learning motivation on basic volleyball technical skills of students of Bung Hatta University Health and Recreation Health and Education Study Program, Bung Hatta University. The purpose of this study is to analyze the differences of the influence of circuit training methods and circuit series and to see students' learning motivation towards their basic skills of volleyball. This research was conducted at Bung Hatta University volleyball court. This study was a quasi experiment with quantitative approach. The technique of data analysis was t-test. Based on the results of data analysis, it was found that: 1) there was a significant effect between the method of circuit training on volleyball basic technical skills with $t_{\text {count }}=16.90$ and $\left.t_{\text {table }}=2.20 ; 1\right)$ there was a significant influence between the circuit series method on the basic skills of volleyball with $t_{\text {count }}=9.62$ and $t_{\text {table }}=$ 2.20 ; 3 ) student learning motivation variables obtained the achievement level of $76.52 \%$. This means that students have good learning motivation in following basic volleyball skills training, which is in the good category.
\end{abstract}

Copyright (C) Universitas Pendidikan Ganesha. All rights reserved.

\section{Introduction}

With the education process, a situation that is balanced between individual aspects and social aspects can be developed. "Education is the reconstruction of various experiences of events experienced by individuals so that all new things become directed and meaningful and the main goal is to increase devotion, intelligence, skills, character, personality and foster a superior generation that can build itself and jointly responsible for development nation ", Malik (2013: 631). One of the educational processes carried out to explore the potential that exists in someone is education carried out in college. The learning process in higher education is better known as lecture. The Jasman Health and Recreation Education Study Program is one of the study programs in the Teaching and Education Faculty which organizes lectures in various subjects including volleyball courses. The achievement of the volleyball lecture is expected that students can have good knowledge and basic skills in volleyball. The basic skills of volleyball are the mastery of techniques which include service technique, top passing and lower passing. This means that students can pass the volleyball course must control the three basic techniques of volleyball. In order for students to master the basic skills of volleyball, students must do the exercises properly with the use of effective methods to be able to improve the basic skills of volleyball in each lecture face to face.

Based on the problems found that it is not good for the basic skills to play a student volleyball can be seen when students do service, namely: (a) the touch of the ball on the hand or finger cannot be controlled towards the desired target, (b) the ball is hit uncontrollably ( c) the ball goes far or out, (d) the ball goes too sharp up and the ball is touched improperly so that when doing service it often fails to cross the ball to the opponent's playing area. Next for deficiencies or mistakes in doing the upper passing, 
namely: (a) the wrong hand and finger attitude (the fingers do not open wide), (b) the attitude of the arms and legs wrong, (c) the ball passed too low, (d) the ball is pulled or taken too far so that there are many mistakes in the students in doing the passing. Furthermore, the error in doing the lower passing, namely: (a) ball acceptance is not controlled (ball deviated) and the body position is often not behind the ball, (b) double reflections occur or the arms are not tight, hands do not stick to each other, (c) The ball is rolling over the arm. In the game of volleyball, one of the difficulties experienced by students is mastering basic techniques, especially in service skills, under-passing and top passing. These two basic techniques are important to master because this technique is widely used in basic level volleyball games. To do passing and service requires dexterity, fast movement, good eye and hand coordination, arm and hand strength and mental readiness are needed.

Some of the factors that can influence the basic skills of volleyball include the available facilities and infrastructure, learning motivation, the physical condition of students, the learning media used, the concentration of students in learning, the readiness of students in learning, the learning environment and the use of appropriate and effective methods. According to Saptono (2013: 111) "Methods that can be used in lectures are command methods, training methods, reciprocal methods, self-check methods, and inclusion methods." The method is the way in which its function is a means to an end. The better the method the more effective the achievement of goals. To determine which method can be called good, a benchmark is needed which comes from several factors that have been stated above. But the main factor that determines is the goal to be achieved. In improving the basic skills of volleyball, it is necessary to know students' motivation to learn and determine specific learning methods and several other methods. The use of methods and forms of training that might lead to an increase in the basic skills of the student's volleyball is by the circuit method and the method of playing series. Circuit training method is one of the training methods that influences the improvement of techniques by using postal training, where each post has a different form of activity from one another. In achieving the training objectives, the training must be in accordance with the principles of training, therefore the provision of technical training must refer to the objectives to be achieved, namely in order to influence the improvement of the technique, if the program is organized

\section{Method}

The research model used is quantitative research with the approach used is a quasi-experimental comparative causal model. The design of the study used in this study was an experiment. Data collection techniques are as follows: 1. Measurement of basic volleyball technical skills consisting of service tests, under-passing and top passing and 2. Data on student learning motivation was collected using a questionnaire with a Likert scale using alternative answers namely: Always (SL) score 4, Often (SR) score 3, Sometimes (KD) score 2, and Never (TP) score 1.

\section{Findings and Discussion}

\section{1) Pre-test Data of Circuit Training Mtehod Group's Volleyball Basic Techical Skill}

From the results of the sample measurements in this group, 12 samples were found to have the highest score of 60 , the lowest score of 23 (range) 37. The mean was 41.92, the median was 42 , then the standard deviation was 10.71. The frequency distribution can be described in table 1 .

Table 1. Frequency Distribution of Volleyball Basic Technical Skill Pre-test Data

\begin{tabular}{cccc}
\hline No & Interval Class & frequency & absolute \\
& $53-50$ & 3 & relative \\
\hline 1 & $45-52$ & 2 & 25 \\
2 & $37-44$ & 4 & 16,67 \\
3 & $29-36$ & 2 & 33,33 \\
4 & $21-28$ & 1 & 16,67 \\
5 & Total & 12 & 8,33 \\
& & & 100 \\
\hline
\end{tabular}


able 1 shows that there is only 1 person (8.33\%) in the interval class $21-28,2$ people $(16.67 \%)$ in the interval class $29-36,4$ people (33.33\%) in the interval class $37-44,2$ people $(16.67 \%)$ are in the 45 52 interval class, and as many as 3 people (25\%) are in the $53-50$ interval class. To be clearer the results of the calculation and description of data frequency distribution result from the technical skills test the base of the volleyball group circuit training method can be seen in the following figure.

\section{2) Post-test Data of Circuit Training Mtehod Group's Volleyball Basic Techical Skill}

The results of the sample measurements in this group, consisting of 12 sample people found the highest score of 81 , the lowest score of 47 , (range) 34 . The mean of 64.52 , median is 63 , then the standard deviation is 9.71. The frequency distribution can be described in table 2 .

Table 2. Frequency Distribution of Volleyball Basic Technical Skill Post-test Data

\begin{tabular}{cccc}
\hline No & Interval Class & absolute & frequency \\
\hline 1 & $75-81$ & 1 & relative \\
2 & $68-74$ & 3 & 8,33 \\
3 & $61-67$ & 5 & 25 \\
4 & $54-60$ & 1 & 41,67 \\
5 & $47-53$ & 2 & 8,33 \\
& Total & 12 & 16,67 \\
\hline
\end{tabular}

\section{3) Pre-test Data of Play Series Method Group's Volleyball Basic Techical Skill}

From the results of the sample measurements in this group, 12 samples were found to have the highest score of 57, the lowest score of 23 (range) 34. The average was 40.92, median was 42, then the standard deviation was 10.81. The frequency distribution can be described in table 3 .

Table 3. Frequency Distribution of Volleyball Basic Technical Skill Post-test Data

\begin{tabular}{cccc}
\hline No & Interval Class & absolute & frequency \\
\hline 1 & $51-57$ & 2 & relative \\
2 & $44-50$ & 4 & 16,67 \\
3 & $37-43$ & 2 & 33,33 \\
4 & $30-36$ & 2 & 16,67 \\
5 & $23-29$ & 2 & 16,67 \\
& Total & 12 & 16,67 \\
\hline
\end{tabular}

\section{4) Post-test Data of Play Series Method Group's Volleyball Basic Techical Skill}

From the results of the measurement of samples in this group, 12 samples were found to have the highest score of 77, the lowest score was 50, (range) 27. The mean was 63.33, median was 64, then standard deviation was 7.24. The frequency distribution can be described in table 4 .

Table 4. Frequency Distribution of Volleyball Basic Technical Skill Post-test Data

\begin{tabular}{cccc}
\hline No & Interval Class & frequency & \\
& & absolute & relative \\
\hline 1 & $72-77$ & 1 & 8,33 \\
2 & $66-71$ & 3 & 25 \\
3 & $60-65$ & 5 & 41,67 \\
4 & $54-59$ & 2 & 16,67 \\
\hline
\end{tabular}




\begin{tabular}{|c|c|c|c|}
\hline 5 & $48-53$ & 1 & 8,33 \\
\hline \multicolumn{2}{|r|}{ Total } & 12 & 100 \\
\hline
\end{tabular}

\section{5) Students' Learning Motivaion}

The data of learning motivation variables from 24 students of Education and Training Department of the Teaching and Education Faculty Study Program obtained the highest score of 135 and the lowest score of 90 , while the range (measurement distance) 45 . The score distribution yielded a mean score of 107.13 and standard deviation (standard deviation) of 11.17. In this analysis all answers from respondents were arranged according to the variables and indicators, and processed in the form of frequency distribution and level of achievement of variables using ideal score analysis of student motivation in Education and Education Faculty in the training of basic volleyball skills.

Of the 24 students of the Education and Training Faculty Teaching and Education Study Program, by submitting 35 items of statements found based on the results of student answers the total number of "always" answers was 345 (41.07\%), the total number of "frequent" answers was 257 (30.60 \%), the total number of answers "sometimes" is $182(21.67 \%)$ and the total number of answers "never" is $56(6.67 \%)$. Thus the level of achievement of student motivation is $76.52 \%$. To be clearer, the distribution of student motivation data results can be seen in table 5 .

Table 5. Data Distribution of Students' Motivation Variabel

\begin{tabular}{cccc}
\hline $\begin{array}{c}\text { Alternative } \\
\text { Options }\end{array}$ & Sum of Answers & $\begin{array}{c}\text { Percentage (\%) } \\
\text { Frequency }\end{array}$ & Achievement Level \\
Selalu & 1380 & 41,07 & \\
Sering & 771 & 30,60 & $76,52 \%$ \\
Kadang-Kadang & 364 & 21,67 & \\
Tidak Pernah & 56 & 6,67 & \\
Jumlah & 2571 & 100 & \\
\hline
\end{tabular}

Based on table 5 above, it is clear that for the student learning motivation variable obtained the achievement level of $76.52 \%$. According to Arikunto (1989: 155) the classification of values $61 \%-80 \%$ is in the "Good" category. This means that students have good learning motivation in following training in basic volleyball skills, which is in the good category.

\section{Prerequisite Data Analysis Testing}

Testing the hypothesis in this study is the normality test as follows. The normality test was carried out using the Lilliefors test with a real level $(\alpha)=0.05$, the testing criterion was that Ho was rejected if Lo was obtained from observational data exceeding Ltdan whereas Ho was accepted if Lt was greater than Lo. The test results for the initial test data of the circuit training method group are the observations of $0.137<$ Ltable 0.242 . It can be concluded that the data are normally distributed. The test results for the initial test data group method of the play series is the Observation $0.112<$ Ltable 0.242 , meaning that the data are normally distributed. Furthermore, the results of testing the final test data of the circuti training method group were found to be observed at $0.121<$ Ltable 0.242 and the final test data of the play series method group obtained observations of $0.177<$ Ltable 0.242 . This means that the data is concluded that the data is normally distributed.

\section{Hypothesis Testing}

After the analysis of the requirements test is carried out and it turns out that all the research variable data meet the requirements for further statistical testing, namely hypothesis testing. The following are described the results of testing of the three research hypotheses, namely:

\section{There was significant influence of Ccircuit training method towards volleyball basic technical skill}

The statistical test used is the t-test, which is to see the effect of the calculated average in the same group with a significant level of 0.05 . The results of the initial test of basic volleyball skills using the circuit training method with a sample of 12 people obtained an average count of 41.92 and a standard deviation was 10.71 . Whereas for the average value of the final test count is 64.25 and the standard deviation is 
9.71. The results of the testing of the first hypothesis found that $t$ count $=16.90>t$ table $=2.20$. This means that the research hypothesis can be accepted. Thus it can be concluded that the method of circuit training has a significant influence on the basic skills of volleyball. The improvement of volleyball's basic technical skills is 22.33, which is from the average score of the initial test 41.91 and the final test becomes 64.25.

\section{There was significant influence of play series method towards volleyball basic technical skill}

The statistical test used is the t-test, which is to see the effect of the calculated average in the same group with a significant level of 0.05 . The results of the initial test of basic volleyball skills using the play series method with a sample size of 12 people obtained an average count of 40.91 and the standard deviation was 10.81. Whereas for the final value of the final test (post test) is 63.33 and the standard deviation is 7.24. The results of testing the second hypothesis found that $t=9.62>t$ table $=2.20$. This means that the research hypothesis can be accepted. Thus it can be concluded that the play series method has a significant influence on the basic skills of volleyball. Improved basic skills in volleyball are 22.42, from the average score of the initial test of 40.91 and the final test to 63.33 .

\section{There was significant difference between circuit training method and play series method towards volleyball basic technical skill}

The statistical test used is the t-test, which is to see the effect of the calculated average in the same group with a significant level of 0.05 . The results of the final test of basic volleyball skills using the circuit training method with a sample size of 12 people obtained an average count of 78.92 and the standard deviation was 10.08. Whereas for the average value of the final test count the play circuit method is 63.65 and the standard deviation is 8.01. The results of testing the third hypothesis found that $t$ count $=0.262$ abel $t$ table $=2.18$. This means that the research hypothesis can be accepted empirically. Thus it can be concluded that there is no significant difference in effect between the circuit training method and the circuit method of playing with basic volleyball technical skills. But based on the results of the final test of basic volleyball technical skills using the circuit training method obtained an average value of 64.25 calculated and the method of playing circuit 63.33 with a difference in the average value of only 0.92 .

\section{Conclusion and Suggestions}

Based on the results of the research data analysis that has been carried out, it can be concluded that: 1) the circuit training method has a significant influence on the basic skills of volleyball, 2) the play series method has a significant influence on the basic skills of volleyball, 3) there is no influence significant between circuit training methods and the circuit method of playing with basic volleyball technical skills, but when viewed from differences in average values, better or more optimal circuit training methods are used to improve basic volleyball technical skills, 4) student learning motivation in taking skills training volleyball is in a good category or in other words students have high motivation in learning volleyball.

\section{References}

A.M. Sardiman, 2007, Interaksi dan Motivasi Belajar Mengajar: Bandung, Rajawali Pers.

Ahmad Adib An'Amta dan Nurhikmahyanti Desi. 2014. Hubungan Motivasi Belajar Olahraga Dan Sarana Prasarana Keolahragaan Terhadap Prestasi Belajar Siswa Cabang Olahraga Voli Pantai Di Upt Sma Negeri Olahraga Provinsi Jawa Timur. Jurnal Inspirasi Manajemen Pendidikan, Vol. 3 No. 3.

Astuti Yuni 2017. Pengaruh Metode Drill dan Metode Bermain Terhadap Keterampilan Bermain Bolavoli Mini (Studi Eksperimen Pada Siswa SD Negeri 14 Kampung Jambak Kecamatan Koto Tangah Kota Padang). Jurnal Al Ibtida. Vol 4 No. 1.

Barzouka K., Sotiropoulos, K., Kioumourtzoglou, 2015. The effect of feedback through an expert model observation on performance and learning the pass skill in volleyball and motivation. Journal of Physical Education and Sport @ (JPES), 15(3), Art 61, pp. 407 - 416

Dimyati, 2006. Belajar dan Pembelajaran, Jakarta: Rineke Cipta.

Erianti. 2011. Buku Ajar Bolavoli. Padang: FIK UNP. 
Harsono. 1988. Prinsip-Prinsip Pelatihan. Jakarta: Depdikbud Dirjen Dikti P2LPTK.

Hendri Irawadi. 2010. Kondisi Fisik dan Pengukurannya. Padang: FIK Universitas Negeri Padang.

Hidayat Akhmad Slamet Nur. 2015. Peningkatan Pembelajaran Servis Atas Bolavoli. Melalui Metode Team Games Tournament Kelas Xi Mia 5 Sman 1 Sleman. Jurnal Pendidikan Jasmani Indonesia. Volume 11, Nomor 2, November 2015.

Khairul Hadziq. 2013. Pendidikan Jasmani Olahraga dan Kesehatan SMP/MTS Kelas VII. Jakarta: Rama Widya.

Malik Arief Abdul, dkk. 2013. "Ular Tangga Olahraga" Media Permainan Edukatif Untuk Olahraga Dengan Menggunakan Sistem Sirkuit Training Bagi Siswa Kelas X Sma Negeri Ajibarang Tahun Journal of Physical Education, Sport, Health and Recreation (2).

Margiyani. 2008. Pendidikan Jasmani, Olahraga, dan Kesehatan Kls. 4 SD/MI. Jakarta: Bumi Aksara.

Saptono Tri. 2013. Perbedaan Pengaruh Metode Mengajar Reciprocal Dan Self Check Terhadap Peningkatan Keterampilan Teknik Dasar Bolavoli. Jurnal Pendidikan Jasmani Indonesia. Volume 9, Nomor 2.

Sri Wahyuni. 2013. Pendidikan Jasmani, Olahraga dan Kesehatan SMA/MA. Semester 1. Jakarta: Tiga Serangkai Pustaka Mandiri.

Surtiyo. 2013. PJOK (Pendidikan Jasmani, Olahraga dan Kesehatan SMP/MTS. Jakarta: PT Bumi Aksara.

Syafruddin. 2004. Permainan Bolavoli. Padang.: FIK UNP.

Syafruddin. 2011. Ilmu Kepelatihan Olahraga. Padang; UNP Press.

Zan Gao, Leslie Podlog, Chaoqun Huang. 2012. Associations among children's situational motivation, physical activity participation, and enjoyment in an active dance video game. Journal of Sport and Health Science (2) 122-128. 